\title{
Roles of nibrin and ATM/ATR kinases on the G2 checkpoint under endogenous or radio-induced DNA damage
}

\author{
KATHERINE MARCELAIN ${ }^{1}$, CONSUELO DE LA TORRE $^{2 *}$, PATRICIO GONZÁLEZ $^{1}$ \\ and JUANA PINCHEIRA ${ }^{1}$
}

\author{
${ }^{1}$ Programa de Genética Humana, ICBM, Facultad de Medicina, Universidad de Chile, Casilla 70061, Santiago \\ 7, Chile \\ ${ }^{2}$ Centro de Investigaciones Biológicas, CSIC, Ramiro de Maeztu, 9, Madrid-28040, Spain
}

\begin{abstract}
Checkpoint response to DNA damage involves the activation of DNA repair and G2 lengthening subpathways. The roles of nibrin (NBS1) and the ATM/ATR kinases in the G2 DNA damage checkpoint, evoked by endogenous and radio-induced DNA damage, were analyzed in control, A-T and NBS lymphoblast cell lines. Short-term responses to G2 treatments were evaluated by recording changes in the yield of chromosomal aberrations in the ensuing mitosis, due to G2 checkpoint adaptation, and also in the duration of G2 itself. The role of ATM/ATR in the G2 checkpoint pathway repairing chromosomal aberrations was unveiled by caffeine inhibition of both kinases in G2. In the control cell lines, nibrin and ATM cooperated to provide optimum G2 repair for endogenous DNA damage. In the A-T cells, ATR kinase substituted successfully for ATM, even though no G2 lengthening occurred. X-ray irradiation $(0.4 \mathrm{~Gy})$ in $\mathrm{G} 2$ increased chromosomal aberrations and lengthened G2, in both mutant and control cells. However, the repair of radio-induced DNA damage took place only in the controls. It was associated with nibrin-ATM interaction, and ATR did not substitute for ATM. The absence of nibrin prevented the repair of both endogenous and radio-induced DNA damage in the NBS cells and partially affected the induction of G2 lengthening.
\end{abstract}

Key terms: ataxia-telangiectasia, ATM and ATR kinases, caffeine, G2 checkpoint, nibrin (Nbs1), Nijmegen breakage syndrome (NBS)

\section{INTRODUCTION}

Cell response to DNA damage in $\mathrm{G} 2$ involves the activation of a signal transduction pathway, known as the G2 checkpoint, that masters two parallel subpathways. One of these activates the repair of DNA lesions, while the other delays the G2 to mitosis transition (Weinert, 1997; Ward \& Chen, 2004). The latter subpathway is brought about by transient inactivation of the CDK-mitotic cyclin heterodimer, mediated by the ATMChk kinases pathway (Abraham, 2001). This allows the cell to have additional time in G2 to repair its damaged DNA before the transition to mitosis takes place (Rhind \& Russell, 2000).
The block in cell cycle progression induced by the G2 checkpoint is always transient, either until all DNA lesions are repaired (recovery) or until the process of checkpoint adaptation makes G2 cells with DNA still unrepaired to jump unduly into mitosis (Pearce \& Humphrey, 2001).

Additional scenarios are possible for a G2 cell that has not yet finished its DNA damage repair. Thus, the cell can become quiescent (dormant), accumulating in what has been known as G0,2 (Sans \& de la Torre, 1979). From this stage, the cell again may reinitiate cycle progression but only when the environmental or endogenous changes reinduce the transcriptional program interrupted earlier. 
In another scenario, the cell initiates the expression of a new transcriptional program leading to its suicide (apoptosis). This option is preferred over checkpoint adaptation when the number of DNA lesions is high. Thus, apoptosis is often the fate of mitotic cells that previously had endured adaptation to the G2 checkpoint. This is due to the rise in chromosomal aberrations generated by the mechanical stress the mitotic process itself imposes on chromosomes (de la Torre et al., 2003a). Finally, the cell may endure irreversible necrosis when the DNA damage is not even compatible with transcription (Kroemer et al., 1998).

In order to understand the roles of the ATM/ATR kinases and of nibrin (Nbs1) in the cell response to endogenous and X-rayinduced DNA damage in G2, lymphoblast cell lines derived from patients with Ataxiatelangiectasia (A-T) or with Nijmegen breakage syndrome (NBS) were compared to those from healthy individuals. The ATM kinase and the nibrin protein are missing or inactive in A-T and NBS cell lines, respectively.

As caffeine inhibits the ATM and ATR kinases (Sarkaria et al., 1999), its shortterm effects on the chromosomal aberrations yield and G2 time were also analyzed in all cell lines. In this way, the role of the ATM kinase would be discriminated from that of the ATR kinase, as well as their interactions with nibrin in the G2 checkpoint.

The ATM kinase is an early transducer of the antimitogenic signals produced in response to DNA damage (de la Torre et al., $2003 \mathrm{~b})$. There are both upstream and downstream ATM interactions with the Mre11 complex (Mre11 nuclease $+\operatorname{Rad50}$ ATPase + nibrin) in the checkpoint pathway evoked by the presence of DNA damage (Uziel et al., 2003; Carson et al., 2003; Motoyama \& Naka, 2004). Thus, the Mre11 complex activates the ATM kinase by phosphorylating it (Lee \& Paull, 2004), though the complex lacking nibrin is also able to activate ATM (Cerosaletti \& Concannon, 2004). In turn, nibrin is phosphorylated by the ATM kinase in response to radio-induced DNA damage (Yuan et al., 2002).
We also analyzed the participation of ATR in the repair of endogenous and radioinduced damage during late G2. The ATR (ATM and Rad3-related) kinase is involved in the repair of UV-induced lesions in G1, of stalled replication blocks in the $S$ period (O'Driscoll et al., 2003), and of the postreplicative DNA damage in G2 (Brown \& Baltimore, 2003). The results obtained in this work show that, in the A-T cells, the ATR kinase substitutes efficiently for the ATM kinase in the repair of endogenous DNA damage. In addition, nibrin increased the repair efficiency of both the ATM and ATR kinases.

\section{METHODS}

\section{Cell lines and cultures}

All cell lines used in this study were Epstein-Barr virus immortalized lymphoblast cells obtained from the Coriell Institute for Medical Research (Camdem, New Jersey, USA). They included: two NBS cell lines (GM 07078, GM 15818); three A-T cell lines (GM 01526, GM 03189, GM 08436) and two control cell lines (GM 00130, GM 02184).

Cell lines were cultured in RPMI 1640 medium (Gibco, USA) supplemented with $15 \%$ heat-inactivated fetal calf serum (Gibco, USA), 2 mM L-glutamine (Gibco, USA), 100 units/ml penicillin and $100 \mu \mathrm{g} /$ $\mathrm{ml}$ streptomycin. They were grown at $37^{\circ} \mathrm{C}$ in a humidified atmosphere of $5 \% \quad \mathrm{CO}_{2}$. Cells taken for the experiments were in an exponential phase of growth.

\section{Chromosome preparations and aberrations scoring}

Metaphase chromosome spreads were obtained from proliferating cell cultures treated with $0.2 \mu \mathrm{g} / \mathrm{ml}$ colcemide (Karyo Max, Gibco, USA) during the last 3 hours before harvesting. Chromosome preparations were produced according to the standard airdrying method and stained with $3 \%$ Giemsa (Merck, Germany). A minimum of 50 metaphases were scored for the presence of chromosome- and chromatid-type aberrations, 
in repeated experiments. Chromosomal aberrations included chromatid and isochromatid breaks, translocations, dicentrics and ring chromosomes. Chromatid/ isochromatid breaks were classified when the distal segments were dislocated from the chromosome axis or when the unstained segment was larger than the chromatid width. A dicentric chromosome plus an acentric fragment were scored as one single aberration.

\section{Caffeine treatment}

Caffeine (Merck, Germany) was dissolved in RPMI 1640 medium to obtain a $50 \mathrm{mM}$ fresh stock solution, for each experiment. Caffeine treatment at the final $5 \mathrm{mM}$ concentration together with colcemide was done during the last 3 hours before harvesting.

\section{$X$-ray irradiation conditions}

For experiments with X-ray-irradiated cells, actively proliferating asynchronous cultures of NBS, A-T and control cell lines were simultaneously irradiated with $0.4 \mathrm{~Gy}$. Xrays were generated by Philips radiotherapy equipment, operated at $180 \mathrm{kV}, 10 \mathrm{~mA}, 4$ $\mathrm{mm} \mathrm{Al}$ filter, at a dose rate of $0.4 \mathrm{~Gy} / \mathrm{min}$. The irradiation time was 1 minute at room temperature $\left(18-20^{\circ} \mathrm{C}\right)$. Immediately after the irradiation, the cultures were relocated to the incubator at $37^{\circ} \mathrm{C}$ and harvested 3.5 hours later.

\section{Determination of $G_{2}$ duration}

The $\mathrm{G}_{2}$ timings for NBS, A-T and control cells lines, under control and X-ray irradiation conditions, were estimated using a method involving autoradiography, as previously described (Pincheira et al., 2001). In short, cell cultures were incubated with $\left[{ }^{3} \mathrm{H}\right] \mathrm{TdR}(25 \mathrm{Ci} / \mathrm{mmol}$ specific activity, from Radiochemical Centre, Amersham, $\mathrm{UK})$ at a final concentration of $1 \mu \mathrm{Ci} / \mathrm{ml}$ culture medium for the last 4, 5, 6 or 7 hours before harvesting. In experiments designed to analyze $G_{2}$ timing under $X$-ray irradiation conditions, cell cultures were irradiated 30 min before the incubation with $\left[{ }^{3} \mathrm{H}\right] \mathrm{TdR}$.

\section{Statistical analysis}

The significance of the differences in the chromosomal aberrations frequency and $\mathrm{G}_{2}$ timing between control and A-T or NBS cell lines, under basal or X-ray irradiated conditions as well as after caffeine treatments, were estimated by Student's t test.

\section{RESULTS}

Chromosomal aberrations and G2 timing in $A-T, N B S$ and control lymphoblast cell lines under basal conditions (constitutive endogenous DNA damage)

Table 1A shows that in the A-T cell lines (with nonfunctional ATM kinase) and in the NBS cell lines (lacking nibrin), the constitutive frequency of chromosomal aberrations $(\mathrm{CA})$ was higher $(14.9 \pm 2.1$ and $38.9 \pm 15.7$, respectively) than in the controls $(7.1 \pm 1.7)$. Thus, nibrin and the ATM kinase (or the ATR kinase in the absence of ATM) are required for the repair of endogenous DNA lesions. Moreover, chronic absence of nibrin may be responsible for the maintenance of a level of constitutive endogenous DNA damage higher than that observed in the chronic absence of the ATM kinase, when both NBS and A-T cells lines are cultured under otherwise similar conditions.

G2 duration in control, A-T and NBS cell lines growing under basal conditions are shown in Table 1A. The G2 timing in control cells was larger $(4.93 \pm 0.2)$ than both in the ATM-deficient and nibrindeficient cell lines $(4.22 \pm 0.1$ and $4.25 \pm$ 0.2 , respectively). The lack of $\mathrm{G} 2$ enlargement detected in both the A-T and NBS cells may be related to the lack of nibrin-ATM kinase interactions.

Response to caffeine-induced ATM/ATR inhibition in $G 2$ in control, $A-T$ and NBS cell lines under endogenous DNA damage

To evaluate the participation of nibrin, ATM and ATR in the repair of endogenous DNA damage during G2, we studied the short-term response to $5 \mathrm{mM}$ caffeine 
inhibition of both kinases (Sarkaria et al., 1999), during the last 3 hours before mitosis. In control cell lines, such treatment increased the basal aberration yield from $7.1 \pm 1.7$ to $15.9 \pm 3.1$ (Table IB). This level was similar to that detected in the A-T cell lines under basal conditions (14.2 \pm 2.1) (Table 1A). In addition, in the A-T cells lacking ATM, the additional inhibition of the ATR kinase by caffeine in G2 roughly doubled the $\mathrm{CA}$ frequency in the ensuing mitosis (from $14.9 \pm 2.1$ to $27.3 \pm$ 5.0) (Table IA). This indicates that the ATR kinase is involved in the repair of endogenous damage during G2 in the A-T cell lines. In the NBS cell lines, caffeine treatment did not modify significantly $(p>0.05)$ the CA frequency in relation to the untreated basal conditions $(33.4 \pm 15.7$ vs . $48.7 \pm 15.1)$.

The inhibition of both ATM and ATR kinases by caffeine treatments during G2 decreased the $\mathrm{G} 2$ timing in the control cell lines (from $4.93 \pm 0.1$ to $4.53 \pm 0.1$ ) but not in any of the mutant cell lines (Table IB). G2 timings were shorter $(4.35 \pm 0.1$ and $4.20 \pm 0.1$ hours long). In the mutant A-T and NBS cell lines, however, their basal G2 timing $(4.22 \pm 0.1$ and $4.25 \pm 0.2$ hours, respectively) was not modified by the inhibition of ATM/ATR kinases (4.35 \pm 0.1 and $4.20 \pm 0.1$ hours, respectively) (Tables IA and B).

Short-term responses to DNA damage radio-induced in $G 2$

Table IIA shows the effect of X-ray irradiation during $\mathrm{G} 2$ on the chromosomal aberration yield and on G2 timing in control, A-T and NBS cell lines. After Xray irradiation $(0.4 \mathrm{~Gy})$ in $\mathrm{G} 2$ (3.5 hours before cell harvesting), CA frequency in the control cell lines increased about 10-fold (up to $68.7 \pm 11.0$ ) in relation to nonirradiated conditions $(7.1 \pm 1.7)$ (Table IA). The aberration yield increment was still greater in the A-T and NBS lymphoblast cells (20- and 26-fold, respectively) than in the non-irradiated ones (Tables IIA and IA, respectively). These data confirm the high radiosensitivity of these mutant cell lines.

Chromosomal aberrations (CA) frequency and G2 timing in control, A-T and NBS lymphoblast cell lines. (A) Basal conditions under endogenous DNA damage. (B) Responses to ATM/ATR inhibition by caffeine during G2.

Cell line Checkpoint proteins CA per 100 metaphases $(*)$ G2 timing (h) (*)

\begin{tabular}{|c|c|c|c|}
\hline Control & nibrin, ATM, ATR & $7.1 \pm 1.7$ & $4.93 \pm 0.2$ \\
\hline$A-T$ & nibrin, - , ATR & $14.9 \pm 2.1$ & $4.22 \pm 0.1$ \\
\hline NBS & -, ATM, ATR & $38.9 \pm 15.7$ & $4.25 \pm 0.2$ \\
\hline
\end{tabular}

B.- Short-term response to caffeine-induced ATM/ATR inhibition in G2

$\begin{array}{lccc}\text { Control +caffeine } & \text { nibrin } & 15.9 \pm 3.1\left(^{\mathrm{a}}\right) & 4.53 \pm 0.1\left(^{\mathrm{a}}\right) \\ \mathrm{A}-\mathrm{T}+\text { caffeine } & \text { nibrin } & 27.3 \pm 5.0\left(^{\mathrm{a}}\right) & 4.35 \pm 0.1 \\ \text { NBS }+ \text { caffeine } & \text { nibrin } & 48.7 \pm 15.1 & 4.20 \pm 0.1\end{array}$

(*) Mean values \pm SD from four different experiments. (a) Significantly different from the basal constitutive condition in A ( $\mathrm{p} \leq 0.05$, Student's $t$-test) 


\section{TABLE II}

Short-term effects on chromosomal aberrations (CA) and G2 timing in control, A-T and NBS lymphoblast cell lines. (A) Response to ionizing radiation (0.4 Gy X-rays) in G2. (B) Response to ATM/ATR inhibition by caffeine treatment during G2.

\begin{tabular}{|c|c|c|c|}
\hline Cell line & Checkpoint proteins & CA per 100 metaphases $(*)$ & $\mathrm{G} 2$ timing $(\mathrm{h})(*)$ \\
\hline \multicolumn{4}{|c|}{ A.- G2 radio-induced DNA damage } \\
\hline Control + X-rays & nibrin, ATM, ATR & $68.7 \pm 11.0$ & $6.05 \pm 0.1\left({ }^{b}\right)$ \\
\hline A-T + X-rays & nibrin, - , ATR & $131.1 \pm 11.9$ & $5.38 \pm 0.2(\mathrm{~b})$ \\
\hline NBS + X-rays & - , ATM, ATR & $156.1 \pm 15.1$ & $5.68 \pm 0.1\left({ }^{b}\right)$ \\
\hline \multicolumn{4}{|c|}{ B.- Short ATM/ATR inhibition by caffeine in G2 of irradiated cells } \\
\hline Control + X-rays + & feine nibrin & $117.6 \pm 11.0\left({ }^{a}\right)$ & $5.46 \pm 0.2^{(a)}$ \\
\hline $\mathrm{A}-\mathrm{T}+\mathrm{X}$-rays + caf & nibrin & $142.2 \pm 14.4$ & $5.07 \pm 0.1\left(^{\mathrm{a}}\right)$ \\
\hline $\mathrm{NBS}+\mathrm{X}$-rays+ca & nibrin & $179.5 \pm 12.5$ & $5.42 \pm 0.1\left(^{(a)}\right.$ \\
\hline
\end{tabular}

(*) mean values \pm SD from four different experiments. ( ${ }^{\text {a) }}$ Significantly different from the caffeine-untreated cell lines in A of this Table. ( $\left.{ }^{b}\right)$ Significantly different from data in Table IA. ( $\mathrm{p} \leq 0.05$, Student's $t$-test).

Short-term responses to caffeine-induced abrogation of the ATM/ATR kinases after $X$-ray irradiation in $G 2$

Table IIB shows that, in the irradiated control cell lines, the inhibition of the ATM and ATR kinases by $5 \mathrm{mM}$ caffeine during $\mathrm{G} 2$ increased CA $(117.6 \pm 11.0)$ to a level not different from that detected in the irradiated A-T cell lines without caffeine (131.1 \pm 11.9$)$ (Table IIA). Furthermore, no significant caffeine effect on chromosomal damage was detected in the irradiated A-T cells. Thus, ATR did not substitute for the nonfunctional ATM when facing the repair of radio-induced DNA damage.

In the NBS cell lines, no significant increase in chromosomal aberration yield was produced by caffeine (Table IIB). Thus, in the irradiated cells, the existence of a mutated nibrin would be determinant for the chromosomal aberration increment, in spite of the presence of ATM and ATR.

In relation to the participation of nibrin and both ATM/ATR kinases in G2 length, Table IIA shows that, in the control cell lines, X-rays induced G2 lengthening, from
$4.93 \pm 0.2$ (Table I A) up to $6.05 \pm 0.1$ hours (Table IIA). This is a normal response to radio-induced DNA damage by a functional G2 checkpoint. Mutant cell lines lacking ATM or nibrin also enlarged G2, though to a lesser extent than the control cell lines (Tables IA and IIA). In the A-T cells, the G2 enlargement produced in response to X-rays would be carried out by the ATR kinase and/or nibrin, while in the NBS cell lines, G2 lengthening would be accomplished by functionally active ATM/ATR kinases (Tables IA and IIA).

\section{DISCUSSION}

The processing of DNA lesions during G2 involves the activation of the corresponding checkpoint, which in turn induces the repair of nuclear DNA damage and, also, the lengthening of G2. When DNA repair is not completed in G2, cells unduly jump into mitosis or, in other words, endure checkpoint adaptation (Weinert, 1997). The most obvious consequence of the adaptation to the $\mathrm{G} 2$ checkpoint is that the unrepaired 
DNA damage becomes detectable as chromosomal aberrations in the immediately following mitosis (de la Torre et al., 2003a).

The G2 checkpoint pathway involves nibrin and the activation of ATM and ATR kinases. Both kinases are considered to be sensors of DNA lesions and/or early transducers of the DNA damage signaling and they are inhibited by caffeine (Sarkaria et al., 1999). Thus, caffeine treatment in G2 of control, A-T and NBS lymphoblast cell lines will generate a set of responses useful to discriminate the role of each of the three checkpoint proteins (nibrin, ATM and ATR) on both DNA repair and G2 lengthening.

The present data point out that nibrin is required for the efficiency of the ATM kinase in the repair of endogenous or radioinduced DNA damage and for the full lengthening of $\mathrm{G} 2$, although nibrin by itself was inefficient to evoke the response of such checkpoint subpathways. They also show that the ATR kinase substitutes for the nonfunctional ATM kinase in the A-T cells, but only when dealing with endogenous damage, not when facing the radio-induced one. ATR would be also responsible for the enlargement of $\mathrm{G} 2$ timing under irradiation, but not under the endogenous conditions.

Two possible explanations can be considered for the partial function of the G2 checkpoint pathway in the A-T cell lines. The first possibility that accounts for the complementation of the $\mathrm{G} 2$ defect in the A$\mathrm{T}$ cells may be the nibrin-dependent activation of the Chk2 kinase (Buscemi et al., 2001). Nevertheless, this is an exceptional route, as during G2, Chk2 is the canonical target in G2 of the ATM kinase in the native control cells growing under basal conditions (Chaturvedi et al., 1999; de la Torre et al., 2003b).

A second possibility is supported by the present results: the Chk1 kinase that is targeted by the ATR kinase during replication, i.e., during the intra-S checkpoint (de la Torre et al., 2003b), would be exceptionally activated to operate during G2 in the A-T patients. This is also sustained by the discovery that Chk 1 complements both the G2 lengthening defect observed in the A-T cells and in DNA repair efficiency (Chen et al., 1999). However, this putative activation of the ATR-Chk1 route seems not to be involved in the $\mathrm{G} 2$ repair defect the A-T cells have in response to radio-induced DNA damage, but only to the endogenous oxidative one.

Moreover, according to the present results, the induction of DNA repair and G2 lengthening subpathways are uncoupled in the mutant lymphoblasts. Thus, G2 failed to be enlarged in the A-T and NBS cell lines, though A-T but not NBS lymphoblasts repaired the endogenous DNA damage. In contrast, after irradiation, both mutant cell lines enlarged $\mathrm{G} 2$, though they were unable to repair this kind of DNA damage. As both DNA repair and G2 lengthening subpathways are efficient in the primary cultures of A-T and NBS lymphocytes (Pincheira et al., 1998; 2001; Marcelain et al., 2004), the uncoupling of the two subpathways of the G2 checkpoint detected in the lymphoblast cell lines may derive from their maintenance during multiple subcultures.

The present data altogether suggest that the increased constitutive DNA damage present in the mutant cell lines (NBS $>$ A-T $>$ control) only partially relies on adaptation to the G2 checkpoint. Such differences may depend also on adaptation to other sequential checkpoints, such as those that control the G1 to S transition, the intra-S or the spindle checkpoints. However, the constitutive absence of either nibrin or the ATM kinase would be responsible for the full abrogation of the G2 checkpoint pathway.

Finally, under basal conditions, only a fraction of the constitutive endogenous chromosomal lesions were repaired by ATM or ATR in the G2 of control and A-T cell lines, respectively. These observations discard the accepted definition of checkpoints as mechanisms that prevent, by ensuring DNA repair completion, the instauration of genome instability. Instead, checkpoints would only decrease the frequency of cells with damaged genome ready to initiate random microevolution experiments. 


\section{ACKNOWLEDGMENTS}

We thank Ms. M. Carrascosa and Mr. J.L. Marcilla for their excellent technical contribution, and Mrs. Beryl L. Walker for correcting the English. The work has been partially supported by the Dirección General de Investigación del Ministerio de Educación y Ciencia of Spain (Project BFU2004-03071) and by the MecesupPostgrado UCH of Chile (Project 9903).

\section{REFERENCES}

ABRAHAM RT (2001) Cell cycle checkpoint signaling through the ATM and ATR kinases. Genes Dev 15: 2177-2196

BROWN EJ, BALTIMORE D (2003) Essential and dispensable roles of ATR in cell cycle arrest and genome maintenance. Genes Dev 17: 615-628

BUSCEMI G, SAVIO C, ZANNINI L, MICCICHÉ F, MASNADA D, NAKANISHI M, TAUCHI H, KOMATSU K, MIZUTANI S, KHANNA K, CHEN P, CONCANNON P, CHESSA L, DELIA D (2001) Chk2 activation dependence on Nbs1 after DNA damage. Mol Cell Biol 21: 5214-5222

CARSON CT, SCHWARTZ RA, STRACKER TH, LILLEY CE, LEE DV, WEITZMAN MD (2003) The Mre11 complex is required for ATM activation and the G2/M checkpoint. EMBO J 22: 6610-6620

CEROSALETTI K, CONCANNON P (2004) Independent roles for nibrin and Mre11-Rad50 in the activation and function of Atm. J Biol Chem 279: 38813-38819

CHATURVEDI P, ENG WK, ZHU Y, MATTERB MR, MISHRA R, HURLE MR, ZHANG X, ANNAN S, LU Q, FAUCETTE F, SCOTT GF, LI X, CARR SZ, JOHNSON RK, WINKLER JD, ZHOU BS (1999) Mammalian Chk2 is a downstream effector of the ATM-dependent DNA damage checkpoint pathway. Oncogene 18: 4047-4054

CHEN P, GATEI M, O CONNELL MJ, KHANNA KK, BUGG SJ, HOGG A, SCOTT SP, HOBSON K, LAVIN MF (1999) Chk1 complements the G2/M checkpoint defect and radiosensitivity of ataxia-telangiectasia cells. Oncogene 18: 249-256

DE LA TORRE C, GIMÉNEZ-ABIAN JF, MAGYAR Z, BOGRE L (2003a) Checkpoints in G2 and early mitosis activated in response to DNA structural changes. Recent Res Devel Plant Sci 1: 173-185

DE LA TORRE C, PINCHEIRA J, LÓPEZ-SÁEZ JF (2003b) Human syndromes with genomic instability and multiprotein machines that repair DNA doublestrand breaks. Histol Histopathol 18: 225-243

KROEMER G, DALLAPORTA B, RESCHE-RIGON M (1998) The mitochondrial death/life regulator in apoptosis and necrosis. Ann Rev Physiol 60: 619-642

LEE JH, PAULL TT (2004) Direct activation of the ATM protein kinase by the Mre11/Rad50/Nbs1 complex. Science 304: 93-96

MARCELAIN K, ARACENA M, BE C, NAVARRETE CL, MORENO R, SANTOS M, PINCHEIRA J (2004) Caracterización clínica, citogenética y molecular de un nuevo caso de síndrome de Nijmegen en Chile. Rev Méd Chile 132: 211-218

MOTOYAMA N, NAKA K (2004) DNA damage tumor suppressor genes and genomic instability. Curr Opin Genet Dev 14: 11-16

O DRISCOLL M, RUIZ-PÉREZ VL, WOODS CG, JEGGO PA, GOOSHIP JA (2003) A splicing mutation affecting expression of ataxia-telangiectasia and $\operatorname{Rad} 3$-related protein (ATR) results in Seckel syndrome. Nat Genet 33: 497-501

PEARCE AK, HUMPHREY TC (2001) Integrating stressresponse and cell-cycle checkpoint pathways. Trends Cell Biol 11: 426-433

PINCHEIRA J, BRAVO M, SANTOS MJ (1998) G2 repair in Nijmegen breakage syndrome: G2 duration and effect of caffeine and cycloheximide in control and Xray irradiated lymphocytes. Clin Genet 53: 262-267

PINCHEIRA J, BRAVO M, NAVARRETE MH, MARCELAIN K, LÓPEZ-SÁEZ JF, DE LA TORRE C (2001) Ataxia-telangiectasia: G2 checkpoint and chromosomal damage in proliferating lymphocytes. Mutagenesis 16: 419-422

RHIND N, RUSSELL P (2000) Chk1 and Cds1: Lichpins of the DNA damage and replication checkpoint pathways. J Cell Sci 113: 3889-3896

SANS J, DE LA TORRE C (1979) G0 and G0,2 cells as identified by their chromatin pattern in dormant and proliferating meristems. Eur J Cell Biol 19: 294-298

SARKARIA JN, BUSBY EC, TIBBETTS RS, ROOS P, TAYA Y, KAMITZ LM, ABRAHAM RT (1999) Inhibition of ATM and ATR kinase activities by the radiosensitizing agent, caffeine. Cancer Res 59: 43754382

UZIEL T, LERENTHAL Y, MOYAL L, ANDEGEKO Y, MITTELMAN L, SHILOH Y (2003) Requirement of the MRN complex for ATM activation by DNA damage. EMBO J 22: 5612-5621

WARD I, CHEN J (2004) Early events in the DNA damage response. Curr Top Dev Biol 63: 1-35

WEINERT T (1997) A DNA damage checkpoint meets the cell cycle engine. Science 277: 1450-1451

YUAN SS, CHANG HL, HOU MF, CHAN TF, KAO YH, WU YC, SU JH (2002) Neocarzinostatin induces Mre11 phosphorylation and focus formation through an ATM- and NBS1-dependent mechanism. Toxicology 177: $123-130$ 